\title{
Rethinking Democracy: A Discourse on Municipalised Democracy and Translocal Citizenship
}

\author{
ŽIGA VODOVNIK
}

\begin{abstract}
This paper discusses a genuinely new political alternative. It is about the alter-globalization movement (AGM), one founded on municipalized - yet global - democracy, horizontalism, and decentralization. The paper starts from the assumption that for a long time, the most important political innovations have not come from the traditional centres of political power, but they have instead been invented by the "newest social movements". It tackles some of the topical debates on global, world and cosmopolitan citizenship in the light of a conceptualization of translocal citizenship that, in the long run, may prove to be the single most subversive thing the AGM has ever recuperated.
\end{abstract}

KEYWORDS: • alter-globalisation movement $\bullet$ translocal citizenship

- direct democracy $\bullet$ municipalisation

CorresPondence AdDress: Žiga Vodovnik, PhD, Research Fellow, Faculty of Arts and Sciences, Harvard University, Barker Center 225, 12 Quincy Street, Cambridge, MA 02138, email: zigavodovnik@fas.harvard.edu. 

and Translocal Citizenship

1

\section{Introduction}

Two decades after the fall of the Berlin Wall, and in the middle of the global financial and economic crisis, we have discovered that there is a deeper crisis of politics per se where the crisis is not understood as politics' inability to mitigate the contradictions inherent in the current economic model, but as its inability to transcend the very same economic model. Following Nicos Paulantzas (2008: 294-322) and his warning that with the overuse of the word crisis, the word also loses its meaning and clarity, we should, at the very beginning, theoretically elaborate on the concept of crisis and on our own understanding of it.

In the past, an economic and political crisis has been viewed merely as an anomaly or rupture in functioning of the self-regulatory system, as a dysfunctional moment that will be overcome when the balance of the system is restored. This conception of crisis results in myopia that

1. overlooks much of the present crises; it is not perceived as such due to its positive role in consolidating and reproducing the status quo, despite its undemocratic and even anti-democratic inclinations; and

2. equates the crisis with various ruptures that are inherent to the hegemonic economic paradigm without representing a threat to its functioning because they are a permanent part of its consolidation and reproduction. (ibid.)

The current crisis is therefore an economic and political crisis in the proper meaning of the word (a "crisis of crisis") because we face such a concentration of contradictions inherent in the system that they now represent a threat to its stability and very survival.

On the other hand, a myriad of innovative solutions can be found within the alterglobalization movement (AGM). ). Gustavo Esteva, a Mexican writer and activist, described it as "one no and many yeses" because many different movements in many different places are united in their critique of neoliberal globalization, whereas their aspirations, goals and visions are diverse (Esteva in Kingsnorth, 2004: 44). In 2001, the first World Social Forum was convened under the event's official slogan "Another World is Possible." Naomi Klein (2002: 193) remarked that the various groups and collectives, gathered in the Brazilian city of Porto Alegre, were not cheering for a specific other world. They just stated the following: "We were cheering for the idea that another world could, in theory, exist."

After the protests against the World Trade Organization summit in Seattle in the late autumn of 1999, the mainstream media tried to dismiss the protesters and their demands with distorted reports that depicted them as "global village idiots" (The Wall Street Journal), "a guerrilla army of anti-trade activists" (The Washington Post), or even as "a Noah's ark of flat-earth advocates, protectionist trade unions, 


\section{LEX LOCALIS - JOURNAL OF LOCAL SELF GOVERNMENT and Translocal Citizenship}

165

and yuppies looking for their 1960s fix" (The New York Times). ${ }^{1}$ Despite the vast amounts of media coverage and plethora of books and articles on the AGM, the movement's innovative solutions and proposals have still not been addressed properly. Therefore, the aim of this paper is to re-examine the solutions and proposals the AGM offers as an alternative to the anomalies of the status quo.

This paper starts from the assumption that for a long time, the most important political innovations have not come from the traditional centres of political power, but they have instead been invented by the "newest social movements" (Day, 2005). ${ }^{2}$ After a short genealogy of the AGM, an analysis of prefigurative politics as a new post-ideology of the AGM follows. In the last part, the paper tackles some of the topical debates on global, world and cosmopolitan citizenship in the light of a conceptualization of translocal citizenship that, in the long run, may prove to be the single most subversive thing the AGM has ever recuperated.

But before we focus on the subject matter, we should highlight the need for a preliminary epistemological transformation that is needed for a proper understanding of the AGM's inspirations and aspirations. Many concepts and solutions offered by the AGM are too elusive for traditional disciplines, classical theories, and Western epistemologies. Therefore, the analysis must be founded on a new and more flexible epistemology. As Arjun Appadurai (2004) has already ascertained, the research in the era of globalization is a peculiar optical challenge.

In the past, many disciplines went through radical epistemological turbulence. These examples can offer us some guiding principles for how to reframe political science that is still overburdened with concepts and research foci from the Cold War. Within the historiography, for instance, the new generation of young scholars of the New Left enabled the discipline to overcome inner limitations no earlier than the 1960s and 1970s. They were best summed up by Henry Kissinger's thesis that history is the memory of states; everything else is of minor importance. Radical historians such as, inter alia, E. P. Thompson, Howard Zinn, Staughton Lynd, and Jesse Lemisch initiated history from the bottom-up, or people's history which, figuratively speaking, moved its focus from those in the White House to those picketing the White House. With this shift alone, the discipline was able to detect new questions and to offer new answers.

For our aims, perhaps more interesting are the current transformations of disciplines within the social sciences and humanities. Particularly beneficial directions for the development of political science can be found in the works of the Portuguese sociologist Boavanture de Sousa Santos. Santos (2004: 238) reasonably warns that there is no global social justice without global cognitive justice. We are witnessing epistemological ignorance that strengthens the status quo, and at the same time, it dismisses, discredits and trivializes arguments and solutions not in accordance with the hegemonic epistemological position - a hegemonic notion of truth, objectivity, and rationality. What is therefore needed is 
an epistemological transformation that will broaden the spectrum of (relevant) political solutions and innovations.

According to Santos, the solution is "the sociology of absences" that transforms impossible objects into the possible ones, absent objects into the present ones, and irrelevant objects into the relevant ones. If the production of non-existence, ergo, the hegemonic conception of political science and sociology, is founded on

1. the monoculture of science that turns modern science and high culture into the sole criteria of truth and aesthetic quality, respectively;

2. the monoculture of linear time that dismisses as "backward" whatever is asymmetrical and contrary to whatever is declared "forward";

3. the monoculture of classification that attempts to naturalize social differences and hierarchies;

4. the monoculture of the universal and the global that trivializes all particular and local practices and ideas, and renders them incapable of being credible alternatives to what exists globally and universally; and

5. the monoculture of capitalist production and efficiency that privileges growth through market forces and dismisses other systems of production as non-productive; (ibid., 233-239)

then "the sociology of absences" should be founded on the following epistemological assumptions:

1. the ecology of knowledge that recognizes other knowledge and criteria of rigour that operate credibly in social practices;

2. the ecology of temporalities that understands linear time as only one of many conceptions of time, and that is not even the most commonly adopted one. The rejection of linear time places other and different political and social practices on the same level as Western political and social practices because they have now become another form of contemporaneity;

3. the ecology of recognition that rejects the colonial ideas of race and sexuality, and tries to articulate the new nexus between the principle of equality and the difference principle, thus allowing for the possibility of equal differences;

4. the ecology of trans-scale that rejects the logic of the global scale and recuperates particular and local practices and ideas as relevant alternatives;

5. the ecology of productiveness that refutes the hegemonic paradigm of development and infinite economic growth. It recuperates and validates alternative systems of production, popular economic organizations, workers' co-operatives, self-managed enterprises, etc., that have been trivialized by the capitalist orthodoxy of productivity. (ibid., 239-240) ${ }^{3}$

"The sociology of absences" thus rescues and reveals the diversity and multitude of political practices and ideas that may inform a credible new counter-hegemonic 


\section{LEX LOCALIS - JOURNAL OF LOCAL SELF GOVERNMENT and Translocal Citizenship}

167

conception of the discipline suitable for the postmodern and globalized world. We should add that the shift would also result in the acceptance of new methodologies, and research focus and ambition that would be the first step towards the pluralization and decentralization of political science. According to Santos, even this would mark the first step towards cognitive justice as a prerequisite for global social justice.

\section{Beyond the Golden Straitjacket}

Thomas L. Friedman, a famous New York Times columnist, concluded his analysis of the effects of (economic) globalization with the daring statement that people should be grateful to be living in a world in which a historical question has been resolved, and the answer is free-market capitalism. In a world in which the invisible hand of the market cannot function without a hidden fist, and McDonald's cannot flourish without McDonnell Douglas, the designer of fighter jets (Friedman, 2000: 443-445).

The neoliberal conception of globalization, says Friedman, forces nation states to finally put on the Golden Straitjacket of liberalization, privatization, and fiscal discipline, which fosters economic growth, although on the political front, the Golden Straitjacket narrows the political and economic policy choices to relatively narrow parameters. "Once your country puts it on, its political choices get reduced to Pepsi or Coke - to slight nuances of taste, slight nuances of policy, slight alterations in design to account for local traditions, some loosening here or there, but never any major deviation from the core golden rules" (ibid., 103). Friedman admits that its "one-size-fits-all" ideology does not suit the specifics of various societies, and therefore the only way to enlarge it is to wear it ever tighter.

To fit into the Golden Straitjacket, a country must either adopt, or be seen as moving towards, the following golden rules: making the private sector the primary engine of its economic growth, maintaining a low rate of inflation and price stability, shrinking the size of its state bureaucracy, maintaining as close to a balanced budget as possible, if not a surplus, eliminating and lowering tariffs on imported goods, removing restrictions on foreign investment, getting rid of quotas and domestic monopolies, increasing exports, privatizing state-owned industries and utilities, deregulating capital markets, making its currency convertible, opening its industries, stock and bond markets to direct foreign ownership and investment, deregulating its economy to promote as much domestic competition as possible, eliminating government corruption, subsidies and kickbacks as much as possible, opening its banking and telecommunications systems to private ownership and competition, and allowing its citizens to choose from an array of competing pension options and foreign-run pension and mutual funds. When you stitch all of these pieces together, you have the Golden Straitjacket. (ibid.) 
Although Friedman sums up his apotheosis of the Golden Straitjacket, ergo, the neoliberal conception of globalization with the conclusion that "the tighter you wear it, the more gold it produces, and the more padding you can then put into it for your society," we can observe nowadays that its stitches have finally broken (ibid., 105). Hence, the proper question that we should ask is not, how to redesign the basic contours of the Golden Straitjacket, but rather how to get rid of it in the first place.

In recent years, many relevant political alternatives to the status quo have been invented by the "newest social movements" (Day, 2005). But writing about the AGM and its political aspirations can be a demanding and also perilous endeavour, particularly if we bear in mind that the AGM is a colourful coalition of ecologists, indigenous activists, farmers, feminists, trade unionists, NGOs and other initiatives that, according to Esteva, offer "one no and many yeses".

Many studies conclude that the AGM was born amid the tear gas and rain that accompanied the anti-WTO protests in Seattle in 1999, but its broader understanding - as an umbrella term under which we can place many different political inspirations and aspirations - opens a new dilemma of where to start with its genealogy. Zahara Heckscher (2002), for instance, traces antecedents of the AGM already back to the late 18th century, more precisely, in the Tupac Amaru II uprising between 1780 and1781. Heckscher believes that uprising represents "a bridge between local anti-colonial rebellion and transnational social movements against exploitative economic integration" (ibid., 86-87). The movement was one of the first to overcome ethnic, religious and even gender differences, and it was also able to connect the European Enlightenment ideas with indigenous cultures. In his seminal history of Latin America entitled Open Veins of Latin America (1973), Eduardo Galeano also detects many regional and global networks of anticolonial resistance that set the beginning of the AGM many decades, if not centuries, before the famous "battle in Seattle". On the other hand, Benedict Anderson concludes in Under the Three Flags (2007) that the global anarchist movement at the end of the 19th century is not only the main ideological inspiration of the AGM, but also its very beginning.

However, if we focus solely on the second half of the "short 20th century", then we can trace the beginnings of the AGM in Liberation Theology in the global South, and in the autonomist movements in the North (e.g., Autonomia in Italy, Autonomen in Germany). Experiences from the 1960s only strengthened the distrust in trade unions and political parties, resulting in a new form of political organization that connected radical workers, students, urban youth, unemployed, indigenous and other marginalized social groups or declassé elements of modern societies that Marx famously dismissed as the lumpenproletariat. It was about this time that the first infoshops, social centres and squats were founded, while the first protests against the growing power of supranational financial institutions were organized. These developments, particularly the protests against the International 
Monetary Fund, often also called "riots for bread", were forecasting the birth of a new global justice movement.

The AGM was born, or at least it came to world attention when the North American Free Trade Agreement (NAFTA) came into force. On that morning, the indigenous people of Chiapas, Mexico, chose to start war against oblivion because the NAFTA - it enabled buying communal land, and on the other hand, it banned subsidies to indigenous farm cooperatives - would bring the "summary execution" of all indigenous people in Mexico. The Zapatista uprising and the later encuentro against neoliberalism and for humanity (Encuentro Intercontinental por la Humanidad $y$ contra el Neoliberalismo) mark the birth of the AGM or the "movement of movements". The encuentro, organized in the Lacandon jungle in 1996 by the Zapatista Army of National Liberation (Ejercito Zapatista Liberation National, EZLN), resulted in an appeal for

intercontinental network of resistance, recognizing differences and acknowledging similarities, [that] will strive to find itself in other resistances around the world. This intercontinental network of resistance will be the medium in which distant resistances may support one another. This intercontinental network of resistance is not on organizing structure; it has no central head or decision maker; it has no central command or hierarchies. We are the network, all of us who resist. (Marcos in de León, 2001: 125)

An important outcome of the Zapatista encuentro, one still often overlooked, is the global network the People's Global Action (PGA) that unites anarchist collectives in Europe and elsewhere with groups ranging from Maori activists in New Zealand, fisherfolk in Indonesia, or the Canadian postal workers' union, and that would become one of the main organizers of the counter-summits from Seattle and Prague, to Quebec and Genoa (Graeber \& Grubačić, 2004). The network includes many movements and collectives that cannot be reduced to a single ideological platform, but as can be seen from its Hallmarks, the organizational principles of the PGA are identical to the main anarchist ideas:

1. A very clear rejection of capitalism, imperialism and feudalism; all trade agreements, institutions and governments that promote destructive globalization.

2. We reject all the forms and systems of domination and discrimination, including but not limited to, patriarchy, racism and religious fundamentalism of all creeds. We embrace the full dignity of all human beings.

3. A confrontational attitude because we do not think that lobbying can have a major impact in such biased and undemocratic organizations in which transnational capital is the only real policy-maker. 
4. A call to direct action and civil disobedience, support for social movement struggles, advocating forms of resistance that maximize respect for life and oppressed peoples' rights, as well as the construction of local alternatives to global capitalism.

5. An organizational philosophy based on decentralization and autonomy. (PGA, 2001)

The story of the AGM then continues with the growing (international) recognition of the Brazilian landless farmers' movement (Movimento dos Trabalhadores Rurais Sem Terra) and of the Indian Karnataka State Farmers' Association (Karnataka Rajya Raitha Sangha); the strengthening of the global coalition of small farmers Via Campesina; the restoration of the international network for the democratic supervision of financial markets and institutions ATTAC (Association pour la Taxation des Transactions por l'Aide aux Citoyens); revolts against privatization of the water system (and rainwater) in Bolivia, privatization of the energy system in South Africa, the "Washington Consensus" policies, and neoliberalism in Argentina; the creation of the international research and education institution The International Forum on Globalization; the organization of the first World Social Forum (Fórum Social Mundial) in Porto Alegre that was followed by regional social forums in Europe, Africa, and Asia; leading to the biggest protests in the history of mankind when on 15 February 2003, over 20 million people all over the world protested against the war in Iraq.

Although the AGM is a diverse "coalition of coalitions", as Klein (2004) described it, and unites various collectives and movements that were often oppositional in the past, the AGM has still managed to develop its own collective identity. However, the AGM's diversity can be viewed as both a fundamental strength and a fundamental weakness. Diversity can come at a high cost, especially "[i]n a political culture that values unity, the AGM's diversity provides opportunities for its critics to disparage it and for security forces to undermine it" (Curran, 2006: 64). What we should address next, therefore, is the AGM's (postideological) connective tissue that manages to preserve its unity in diversity.

According to Giorel Curran (2006: 2), "post-ideological anarchism" represents the main ideological current within the AGM and, at the same time, also its best response to the reconfigured ideological landscape that renders doctrinal purity obsolete. "Post-ideological anarchism" adopts ideas and principles from classical anarchism very flexibly and non-doctrinally, and it simultaneously rejects its traditional forms to construct genuinely new autonomous politics. So, is it possible to talk about a new anarchism within the AGM?

In Dave Neal's essay Anarchism: Ideology or Methodology? we find two basic positions within anarchism - capital-A and small-a anarchism. If capital-A anarchism puts an emphasis on achieving ideological uniformity, and it can be understood as "a set of rules and conventions to which you must abide", then 


\section{LEX LOCALIS - JOURNAL OF LOCAL SELF GOVERNMENT and Translocal Citizenship}

171

small-a anarchism is understood as a methodology or "a way of acting, or a historical tendency against illegitimate authority" (Neal, 1997).

In an essay written before the boom of the AGM, Neal estimated that within the movement, we could still find "a plethora of Anarchists - ideologues - who focus endlessly on their dogma instead of organizing solidarity among workers". A decade later, David Graeber (2004: 214) contemplates that what we might call capital-A anarchism still exists within the AGM, but it is the small-a anarchism that represents the true locus of creativity within the AGM. In his reflection on new anarchism, he stresses that it still has an ideology, but for the first time, it is an entirely new one - i.e., a post-ideology that is immanent in the antiauthoritarian principles underlying its political practice.

A constant complaint about the globalization movement in the progressive press is that, while tactically brilliant, it lacks any central theme or coherent ideology. . . [T] his is a movement about reinventing democracy. It is not opposed to organization. It is about creating new forms of organization. It is not lacking in ideology. Those new forms of organization are its ideology. It is about creating and enacting horizontal networks instead of top-down structures like states, parties or corporations; networks based on principles of decentralized, non- hierarchical consensus democracy. Ultimately, it aspires to be much more than that because ultimately, it aspires to reinvent daily life as a whole. (ibid., 212)

In her paper "Anarchism and the Anti-Globalization Movement", Barbara Epstein also ascertains that anarchism in the AGM represents the main inspiration for a new generation of activists. For them, anarchism does not represent some abstract radical ideology, but instead, it means

a decentralized organizational structure, based on affinity groups that work together on an ad hoc basis, and decision- making by consensus. It also means egalitarianism; opposition to all hierarchies; suspicion of authority, especially that of the state; and commitment to living according to one's values. . . Many envision a stateless society based on small, egalitarian communities. For some, however, the society of the future remains an open question. For them, anarchism is important mainly as an organizational structure and as a commitment to egalitarianism. It is a form of politics that revolves around the exposure of the truth rather than strategy. It is a politics decidedly in the moment. (Epstein, 2001: 1) 

and Translocal Citizenship

\section{The Municipalization of Political Membership and Translocal Citizenship}

In the past, practically every single progressive intellectual current subsumed politics under statecraft. Consequently, their anti-statist position resulted in theoretical purism and anti-intellectualism that rejected every in-depth reflection of key concepts such as political power or even citizenship. According to Murray Bookchin (2007: 93-94), politics and statecraft are not only significantly different, but they are in opposition to each other. Historically, politics has not been and could not be developed within the state because it has always been closer to a philosophical concept of praxis as a free and creative activity of individuals within fluid polities. The modern state, on the other hand, was born as a reactionary response to Renaissance humanism, and it has always been an obstacle to global democracy. ${ }^{4}$ Moreover, for Richard Day (2005: 38), the struggle for dismantlement of a community through demutualization that is being waged between communities on the one hand and state and corporate forms on the other is indeed the struggle of the (post)modern condition.

David Graber also acknowledges that politics and statecraft are in mutual conflict. Graeber (2007: 342) contends that majoritarian democracy, in all its forms, has been a rarity in the history of political communities, because it builds on two factors that only rarely co-exist:

1. belief that people should have an equal say in the decision-making process;

2. a coercive apparatus capable of enforcing those decisions.

Graeber claims that throughout human history, it has been extremely unusual to have both ideas at the same time. In egalitarian societies, it has usually been considered wrong to impose the development of systematic coercion, whereas in polities where a system of coercion did develop, it did not even occur to those wielding it that they were enforcing any sort of popular will.

In the end, the common denominator of the various movements and collectives that comprise the AGM, and also its most interesting contribution at the political and theoretical level can be found in their new understanding of political community and political membership. In the current debates on citizenship, they intervene with communalism and libertarian municipalism that, inter alia, offer a new conceptualization of nomadic citizenship - we might call it translocal citizenship. Translocal citizenship is yet another outcome of the AGM's focus on prefigurative politics as an attempt to create the future in the present with political and economic organization alone, or at least to foresee social changes to which we aspire. It is indeed an attempt to overcome the current limitations with a construction of alternatives from the bottom-up because it foresees a renewal of the political power of local communities, and their federation into a global nonstatist network as an anti-power to nation states and corporate power. 


\section{LEX LOCALIS - JOURNAL OF LOCAL SELF GOVERNMENT and Translocal Citizenship}

173

Communalism and libertarian municipalism suggest the theory of the German anarchist writer Gustav Landauer who, already at the beginning of the 20th century, revealed that for political emancipation, we should overcome the negative fetishization of the state. According to Landauer, an author not well-known outside anarchist circles, the state is rather "a condition, a certain relationship among human beings, a mode of behaviour" that must be theoretically addressed and not rejected merely due to our theoretical purity or ontological principles. Therefore, a state is not something that can be destroyed by means of a revolution, which is why it is necessary to build libertine enclaves next to it, or to postulate a revolution as a "peaceful and gradual creation of counterculture" opposite to the idea of "a revolution as a violent mass rebellion". It is not possible to attain a free society merely by replacing an old order with a new one because it can only be attained by spreading the spheres of liberty to such an extent that they finally prevail over the entire social life. If the state is in all of us, then we can abolish it only by revising our behaviour.

One can overturn a table and smash a windowpane; but they are puffed-up word-spewers [Wortemacher] and gullible word-adorers [Wortanbeter], who hold the state for such a thing - akin to a fetish - that one can smash in order to destroy. The state is a relationship between human beings, a way by which people relate to each other; and one destroys it by entering into other relationships, but behaving differently to each other. . . [W]e must recognize the truth: we are the state - and are it as long as we are not otherwise, as long as we have not created the institutions that constitute a genuine community and society of human beings. (Landauer in Graham, 2005: 165)

Within the AGM, the prefiguration of alternatives is also accepted through Hakim Bey's popular conceptualization of spontaneous and subversive tactics of Temporary Autonomous Zones (TAZ) "which liberates a part (of land, of time, of imagination), and then it dissolves itself to re-form elsewhere/elsewhen before the State can crush it" (Bey, 2003: 99). According to Jeffs' (1997: 368-369) elaboration of Bey's theory of TAZ, the political change should be "deterritorialized, decentralized, and delinearized at political, economic, social, libidinal, and last but not least, at narrative levels, and small and nomadic forms of resistance need to be introduced, also because there is not a single place in the world that has not been delineated by the nation state. . [TAZ] is invisible to the state and flexible enough to vanish when determined, defined, and fixated."

Such emancipation does not have to postpone its mission for the fulfilment of the necessary precondition - the maturity of objective historic circumstances, or the formation of some coherent subject or class - because it builds on the assumption that every individual is capable of co-creating the world with their, even if very small, gestures ( $c f$. Jeffs, 1998: 22-23). Going back to Landauer, the necessary change "concerns every aspect of a human life, not only the state, class structure, 
industry and trade, art, education. . . The path to a new, better social order runs along a dark and fatal road of our instincts and terra abscondita of our souls. The world can only be formed from the inside out" (Landauer in Marshall, 1993: 411412).

The concept of translocal citizenship within the municipalized international community represents a significant departure from classical theories of citizenship because rather than on identity, it builds on inclusion and participation, and instead of equality, it accentuates differences, or "equal differences" (Santos). However, translocal citizenship should not be understood as another postmodern conception of political membership characterized by relativism and particularism. It represents a critique of the universalistic assumptions within the liberal tradition, or their upgrade with differentiated universalism that draws close to Habermas' idea of "constitutional patriotism". 5

Considering that translocal citizenship offers a different understanding of political community, and that it stresses its constant reinvention, we should rather conclude that translocal citizenship represents a form of "unconstitutional patriotism" that in its replacement of ethnos with demos follows a significantly more radical definition of democracy than Habermas. It does not equate democracy with a particular constitutional system only, nor does it with a particular constellation of centres of power within a society, but instead it understands democracy in Westian terms - as a verb, and never as a noun ( $c f$. West, 2005: 68). Hence, translocal citizenship is not limited to the sphere of politics only (an achievement of the eighteenth century), but logically includes all social and economic life. At the same time, the altered nexus between the local, regional, and global makes it possible to finally separate political membership from the national and its constitution according to entirely new criteria. Therefore, translocal citizenship does not represent depoliticization of political membership, but rather a substantive understanding of the concept that has been reduced to a legal status without substance over the past decades. In the long run, the concept with its vision of communitarian nomadism may prove to be the single most subversive thing the AGM has ever recuperated.

\section{$4 \quad$ Closing Remarks}

In his communiqué Siete piezas sueltas del rompecabezas mundial, Subcomandante Marcos (the voice and the strategist of the EZLN) ascertains that with the current processes of economic globalization, the nation-state is being forced to redefine its position and purpose. ${ }^{6}$ Namely, the end of the Cold War brought with it a new framework of international relations, and a redefinition of the nation-state. The structure of the global economy, which has up to now been leaning against the system of sovereign nation-states, is in an irreversible crisis today. In the "cabaret of economic globalization" with the construction of a de- 


\section{LEX LOCALIS - JOURNAL OF LOCAL SELF GOVERNMENT and Translocal Citizenship}

territorialized Empire, the nation-state is being reduced to the indispensable minimum. According to Marcos

[it] shows itself as a table dancer that strips of everything until it is left with only the minimum indispensable garments: the repressive force. With its material base destroyed, its possibilities of sovereignty annulled, its political classes blurred, the nation-states become nothing more than a security apparatus of the megacorporations. (ibid., 271)

Politics as the organizer of nation-states in this "new world order" ceases to exist. Now, politics is nothing more than an economic organizer, and politicians are administrators of companies, while "national" governments are only responsible for the administration of business in different regions of the Empire. This type of political architecture is not a novum, but merely a continuation and perfection of the hegemonic logic which, in a changed environment, consequently took on a new form. According to Marcos (ibid., 258), this is indeed a strange modernity that moves forward by going backward.

From Marcos' description of contemporary political and economic architecture, it can already be seen that nowadays when within the top 100 economies, we find more multinational corporations than national economies, the nation-state ceases to exist as the only centre of sovereignty and arena where crucial political decisions are made. On these grounds, April Carter (2001: 8) calls for a new concept of citizenship that moves away from the idea of nationality, but at the same time, it surpasses the parochial forms of political community that make global connectedness impossible.

The idea of translocal citizenship certainly represents interesting dialectics between the Scylla of the particular and Charybdis of the universal. Nevertheless, we should again stress that this conceptualization of citizenship and political community is not a sheer novelty, as Harold Barclay (1996: 12) concludes in his anthropological study of non-statist polities, it "is by no means unusual; . . it is a perfectly common form of polity or political organization. Not only is it common, but it is probably the oldest type . . . and one which has characterized most of human history."

To sum up, the political vision of the AGM is an antithesis to the hegemonic economic and political paradigm. It stresses that democracy can be and needs to be worked out first on a more manageable scale, ergo, within local communities. Moreover, it prefigures a different political vision that is based on municipalized (yet global) democracy, horizontalism, and decentralization. There is an open space in the political landscape for a new economic and political paradigm. The panacea for "a strange modernity that moves forward by going backward" may no longer be found in Swiss ski resorts and other centres of political power, but we might find it on the margins of the current political map where various 
"subterranean" collectives and movements are developing a genuinely new political alternative.

\section{Notes}

${ }^{1}$ For more information on the media representation of the AGM, see McNally, D. (2006) Another World is Possible: Globalization \& Anti-Capitalism (Winnipeg: Arbeiter Ring Publishing).

${ }^{2}$ For a detailed conceptualization of the "newest social movements", see Day, R. J. F. (2005) Gramsci is Dead, Anarchist Currents in the Newest Social Movements (London: Pluto Press); Curran, G. (2006) 21st Century Dissent: Anarchism, Anti-Globalization and Environmentalism pp. 53-56 (New York, NY: Palgrave,).

${ }^{3}$ For a further elaboration of the sociology of absences, see Santos, B. S. (2004) The World Social Forum: Toward a Counter-Hegemonic Globalisation (Part I), In: Sen, J. (ed.) World Social Forum: Challenging Empires, pp. 235-245 (New Delhi: The Viveka Foundation,); Santos, B. S. (2006) The Rise of the Global Left: The World Social Forum and Beyond (London: Zed Books); Santos, B. S. (ed.) (2007) Cognitive Justice in a Global World: Prudent Knowledge for a Decent Life (Lanham, MD: Lexington Books); Santos, B. S. (ed.) (2008) Another Knowledge Is Possible: Beyond Northern Epistemologies (New York, NY: Verso).

${ }^{4}$ Cf. Mertes, T. (2004) Grass-roots Globalism, In: Mertes, T. (2004) A Movement of Movements, Is Another World Really Possible?, p. 238 (New York, NY: Verso).

${ }^{5}$ See Delany, G. (2006) Citizenship in a global age: Society, culture, politics, pp. 45-47 (New York, NY: Open University Press).

${ }^{6}$ For an English translation of the communiqué, see Marcos, S. (2004) The Seven Loose Pieces of the Global Jigsaw Puzzle, In: vodovnik, Ž. (2004) Ya Basta! - Ten Years of the Zapatista Uprising, pp. 257-278 (Oakland, CA: AK Press).

\section{References}

Anderson, B. (2007) Under Three Flags: Anarchism and the Anti-Colonial Imagination (New York: Verso).

Appadurai, A. (2004) Grassroots Globalization and the Research Imagination, In: Vincent, J. (ed.) The Anthropology of Politics: A Reader in Ethnography, Theory, and a Critique (Malden, MA: Blackwell Publishers).

Barclay, H. (1996) People Without Government, An Anthropology of Anarchy (London: Kahn \& Averill).

Bey, H. (2003) T.A.Z.: The Temporary Autonomous Zone, Ontological Anarchy, Poetic Terrorism (Brooklyn, NY: Autonomedia).

Bookchin, M. (2007) Social Ecology and Communalism (Oakland, CA: AK Press).

Carter, A. (2001) The Political Theory of Global Citizenship (London: Routledge).

Curran, G. (2006) 21st Century Dissent: Anarchism, Anti-Globalization and Environmentalism (New York, NY: Palgrave).

Day, R. J. F. (2005) Gramsci is Dead, Anarchist Currents in the Newest Social Movements (London: Pluto Press).

Delanty, G. (2006) Citizenship in a global age: Society, culture, politics (New York: Open University Press).

Epstein, B (2001) Anarchism and the Anti-Globalization Movement, Monthly Review, 53(4), pp. 1-14. 


\section{LEX LOCALIS - JOURNAL OF LOCAL SELF GOVERNMENT \\ Ž. Vodovnik: Rethinking Democracy: A Discourse on Municipalised Democracy and Translocal Citizenship}

Esteva, G. (2008) The Other Campaign, APPO and the Left: Reclaiming an Alternative, In: Denham, D \& C.A.S.A Collective (eds) Teaching Rebellion, Stories from the Grassroots Mobilization in Oaxaca (Oakland: PM Press).

Friedman, T. L. (2000) The Lexus and the Olive Tree: Understanding the Globalization (New York: Anchor Books).

Galeano, E. (1973) Open Veins of Latin America: Five Centuries of the Pillage of a Continent (New York: Monthly Review Press).

Graeber, D. \& Grubačić, A. (2004) Anarchism, Or The Revolutionary Movement Of The Twenty-first Century. Available at: http://www.zcommunications.org/znet/viewArticle/ 9258 (November 10, 2010).

Graeber, D. (2004) The New Anarchists, In: Mertes, T. (ed.) A Movement of Movements, Is Another World Really Possible? (New York: Verso).

Graeber, D. (2007) Possibilities: Essays on Hierarchy, Rebellion, and Desire (Oakland: AK Press).

Graham, R. (ed.) (2005) Anarchism: A Documentary History of Libertarian Ideas, Volume One: From Anarchy to Anarchism (300CE to 1939) (Montréal: Black Rose Books).

Heckscher, Z. (2002) Long before Seattle: Historical Resistance to Economic Globalization, In: Broad, R. (ed.) Global Backlach: Citizen Initiatives for a Just World Economy (Manham: Rowman \& Littlefield Publishers).

Holloway, J. (2004) Spreminjamo svet brez boja za oblast: pomen revolucije danes (Ljubljana: Študentska založba).

Jeffs, N. (2003) Intelektualci, novi razredi, anarhizmi, In: Chomsky, N. (ed.) Somrak demokracije (Ljubljana: Studia humanitatis).

Jeffs, N. (1998) All you need is love (nasilje, emancipacija, pa tudi nekaj uvodnih besed...), Časopis za kritiko znanosti, domišljijo in novo antropologijo, 26(190/191), pp. 9-42.

Kingsnorth, P. (2003) One No, Many Yeses (London: Free Press, 2003).

Klein, N. (2002) Fences and Windows, Dispatches from the Front Lines of the Globalization Debate (London: Flamingo).

Ponce de Leon, J. (ed.) (2001) Our Word is Our Weapon: Selected Writings of Subcomandante Marcos (New York: Seven Stories Press).

Marshall, P. (1993) Demanding the Impossible, History of Anarchism (New York: HarperCollins Publishers).

Martin, J. (ed.) (2008) The Paulantzas Reader: Marxism, Law and the State (New York: Verso).

McNally, D. (2006) Another World is Possible: Globalization \& Anti-Capitalism (Winnipeg: Arbeiter Ring Publishing).

Neal, D. (1997) Anarchism: Ideology or Methodology?, available at: http://www.infoshop.org/library/Dave_Neal:Anarchism:_ideology_or_methodology (November 10, 2010).

People's Global Action (PGA) Hallmarks, available at: http://www.nadir.org/nadir/initiativ/agp/en/ (November 10, 2010).

Restrepo, E. \& Escobar, A. (2005) Other Anthropologies and Anthropology Otherwise: Steps to a World Anthropologies Framework, Critique of Anthropology, 25(2), pp. 99129, doi: 10.1177/0308275X05053009.

Santos, B. S. (2004) The World Social Forum: Toward a Counter-Hegemonic Globalisation (Part I), In: Sen, J., Anand, A., Escobar, A. \& Waterman, P. (eds) World Social Forum: Challenging Empires (New Delhi: The Viveka Foundation).

Santos, B. S. (2006) The Rise of the Global Left: The World Social Forum and Beyond (London: Zed Books). 
Santos, B. S. (ed.) (2007) Cognitive Justice in a Global World: Prudent Knowledge for a Decent Life (Lanham, MD: Lexington Books).

Santos, B. S. (ed.) (2008) Another Knowledge Is Possible: Beyond Northern Epistemologies (New York, NY: Verso).

Sheehan, S. M. 2003. Anarchism (London: Reaktion Books).

Subcomandante Marcos (2004) The Seven Loose Pieces of the Global Jigsaw Puzzle, In: Vodovnik, Ž. (ed.) Ya Basta! - Ten Years of the Zapatista Uprising (Oakland: AK Press).

Turner, B. \& Hamilton, P. (eds) (2002) Citizenship: Critical Concepts (London: Routledge).

West, C. (2005) Democracy Matters (New York: Penguin Books). 